Solid State Ionics 231 (2013) 43-48

(Doi: 10.1016/j.ssi.2012.10.017)

http://dx.doi.org/10.1016/j.ssi.2012.10.017

\title{
Synthesis and characterization of nano- $\mathrm{LaFeO}_{3}$ powders by a soft- chemistry method and corresponding ceramics
}

\author{
Roberto Köferstein ${ }^{*}$ and Stefan G. Ebbinghaus \\ Institute of Chemistry, Inorganic Chemistry, Martin-Luther-University Halle-Wittenberg, \\ Kurt-Mothes-Strasse 2, 06120 Halle, Germany.
}

* Corresponding author. Tel.: +49-345-5525630; Fax: +49-345-5527028.

E-mail address: roberto.koeferstein@chemie.uni-halle.de

\begin{abstract}
The preparation of a nano-sized $\mathrm{LaFeO}_{3}$ powder by a soft-chemistry method using starch as complexing agent is described herein. Phase evolution and development of the specific surface area during the decomposition process of ( $\mathrm{LaFe})$-gels were monitored up to $1000{ }^{\circ} \mathrm{C}$. A phase-pure nano-sized $\mathrm{LaFeO}_{3}$ powder with a high specific surface area of 25.7 $\mathrm{m}^{2} / \mathrm{g}$ and a crystallite size of $37 \mathrm{~nm}$ was obtained after calcining at $570{ }^{\circ} \mathrm{C}$. TEM investigations reveal a porous powder with particles in the range of 20 to $60 \mathrm{~nm}$. Calcinations to $1000{ }^{\circ} \mathrm{C}$ result in crystallite sizes up to $166 \mathrm{~nm}$. Dilatometric measurements of the sintering behaviour show that the beginning of shrinkage of pellets from the nano-sized powder is
\end{abstract}


downshifted by more than $300{ }^{\circ} \mathrm{C}$ compared to coarse-grained mixed-oxide powder. The orthorhombic $\leftrightarrows$ rhombohedral phase transition was observed at $980{ }^{\circ} \mathrm{C}$ in DTA measurements for coarse-grained ceramic bodies. The enthalpy change $(\Delta H)$ during the phase transition and the thermal expansion coefficient $\left(\alpha_{d i l}\right)$ for ceramics was determined as 410 $\mathrm{J} / \mathrm{mol}$ and $11.8 \cdot 10^{-6} \mathrm{~K}^{-1}$, respectively. Whereas the enthalpy changes during the phase transition of the nano-sized $\mathrm{LaFeO}_{3}$ powders are $\leq 200 \mathrm{~J} / \mathrm{mol}$.

Keywords: Lanthanum orthoferrite; starch; perovskite; ceramic; sintering; soft-chemistry synthesis

\section{Introduction}

Perovskite-related materials based on lanthanum orthoferrite $\left(\mathrm{LaFeO}_{3}\right)$ are of interest because of their broad applications in advanced technologies. $\mathrm{LaFeO}_{3}$ based materials can be used as catalyst for the decomposition of e.g. hydrocarbons, chlorinated Volatile Organic Compounds (VOCs) or by the reaction between $\mathrm{NO}$ and $\mathrm{CO}[1,2,3,4]$. They are also candidates as catalysts in heterogeneous Fenton-like reactions for the wet peroxide oxidation of hydrocarbons $[5,6]$ and as photocatalysts $[7,8]$. Furthermore, doped and undoped lanthanum orthoferrites are applied as sensor materials $[9,10,11]$ and as electrode materials in Solid Oxide Fuel Cells (SOFCs) [12,13,14,15].

$\mathrm{LaFeO}_{3}$ is a ferromagnetic insulator with a Néel temperature of $467{ }^{\circ} \mathrm{C}$ [16]. At room temperature it crystallizes in the orthorhombic perovskite structure and exhibits a phase transition to the rhombohedral modification at about $987^{\circ} \mathrm{C}$ [17].

The conventional mixed-oxide synthesis of $\mathrm{LaFeO}_{3}$ requires high preparation temperatures and long reaction times. It results in powders with low specific surface area which is 
disadvantageous because powders with high specific surface areas can improve the catalytic activity and the densification behaviour of compacts $[18,19]$.

To obtain fine-grained or nano-sized $\mathrm{LaFeO}_{3}$ powders a number of wet-chemical syntheses have been developed such as precursor methods [20,21,22,23], sol-gel and combustion routes [7,24,25]. Nano-sized powders by a microemulsion route were reported by Giannakas et al. [26] and $L i$ et al. [27]. A microwave-assisted synthesis is described by Prado-Gonjal et al. [28]. Liu and $X u$ [29] used glucose as a complexing agent in a sol-gel process to produce nano- $\mathrm{LaFeO}_{3}$. Various thermal synthesis of nano- $\mathrm{LaFeO}_{3}$ results in a porous microstructure of the powders $[7,20,25,30,31,32,33,34,35]$.

The aim of this paper is to describe a simple and fast preparation route to obtain nano-sized $\mathrm{LaFeO}_{3}$ powders using starch as a complexation agent and gellant. We use starch because it is an eco friendly and cheap abundant biopolymer. The phase evolution during the decomposition process was monitored by XRD and thermal analysis. For the obtained nanocrystalline $\mathrm{LaFeO}_{3}$ powders the phase transition temperatures and enthalpy changes from the orthorhombic room-temperature to the rhombohedral high-temperature modification were studied. The sintering behaviour and microstructure of resulting $\mathrm{LaFeO}_{3}$ compacts were determined by dilatometry and SEM.

\section{Experimental}

\subsection{Material preparation}

$\mathrm{La}\left(\mathrm{NO}_{3}\right)_{3} \cdot 6 \mathrm{H}_{2} \mathrm{O}(0.006 \mathrm{~mol}$, Merck $)$ and $\mathrm{Fe}\left(\mathrm{NO}_{3}\right)_{3} \cdot 9 \mathrm{H}_{2} \mathrm{O}(0.006 \mathrm{~mol}$, Merck $)$ were dissolved in $15 \mathrm{ml}$ water and $2 \mathrm{~g}$ soluble starch (Sigma-Aldrich) were added. The turbid solution was continuously stirred at room temperature and after 15 min the heating plate was raised to about $120^{\circ} \mathrm{C}$. After about $5 \mathrm{~min}$ the solution turned to a highly viscous orange gel. This $(\mathrm{LaFe})$-gel was calcined in static air at various temperatures up to $1000{ }^{\circ} \mathrm{C}$ (heating rate 5 $\mathrm{K} / \mathrm{min}$ ). Calcination at $570{ }^{\circ} \mathrm{C}$ for $2 \mathrm{~h}$ yielded a nano-sized $\mathrm{LaFeO}_{3}$ powder (1a), as described 
in detail below. Powder 1a was mixed with 5 mass $\%$ of a saturated aqueous polyvinyl alcohol (PVA) solution as a pressing aid and then the powder was pressed into pellets with a green density of about $1.6-1.7 \mathrm{~g} / \mathrm{cm}^{3}$.

For comparison, a coarse-grained $\mathrm{LaFeO}_{3}$ powder (2) was prepared via a semi-conventional mixed-oxide method. $\mathrm{La}_{2}\left(\mathrm{C}_{2} \mathrm{O}_{4}\right)_{3} \cdot 9 \mathrm{H}_{2} \mathrm{O}$ (SKW Stickstoffwerke Piesteritz GmbH) and $\mathrm{Fe}_{2} \mathrm{O}_{3}$ (Sigma-Aldrich) were ball milled using $\mathrm{ZrO}_{2}$-balls with a molar ratio of 1:1 for $24 \mathrm{~h}$ in $30 \mathrm{ml}$ propan-2-ol using $\mathrm{ZrO}_{2}$-balls. After drying, the mixture was calcined at $1200{ }^{\circ} \mathrm{C}$ for $8 \mathrm{~h}$ (heating rate: $5 \mathrm{~K} / \mathrm{min}$ ) to obtain $\mathrm{LaFeO}_{3}$. Pressing of pellets was carried out as described above. The resulting compacts had a green density of about $4.0-4.1 \mathrm{~g} / \mathrm{cm}^{3}$.

\subsection{Characterization}

X-ray powder diffraction (XRD) patterns were recorded on a STOE STADI MP diffractometer at room temperature using $\mathrm{Co}-\mathrm{K}_{\alpha 1}$ radiation. Powder patterns were refined with the profile fitting software PowderCell [36]. Crystallite sizes were determined from the XRD line broadening using the Scherrer equation [37] and the integral peak breadth (software suite WinXPOW [38]). The Wilson-equation was used to determine the strain parameter $[38,39]$. Dilatometric investigations were performed in flowing synthetic air atmosphere (50 $\mathrm{ml} / \mathrm{min}$ ) in a Setaram TMA 92-16.18 dilatometer. Simultaneous thermogravimetric (TG) and differential thermoanalytic (DTA) measurements in flowing synthetic air $(30 \mathrm{ml} / \mathrm{min})$ were performed using a Netzsch STA 449 system. The TG/DTA measurements of the decomposition of the ( $\mathrm{LaFe})$-gel were carried out on a sample preheated at $200{ }^{\circ} \mathrm{C}$ for $1 \mathrm{~h}$. The specific surface areas (BET) of the $\mathrm{LaFeO}_{3}$ samples were determined using nitrogen three-point gas physisorption (Nova 1000, Quantachrome Corporation). The equivalent BET particle diameters were calculated assuming a spherical or cubic particle shape [40]. ATRFourier transformed infrared (FT-IR) spectra were collected at room temperature using a Bruker Tensor 27 spectrometer equipped with a diamond ATR unit. TEM images were 
recorded with a Philips CM20Twin at an electron energy of $200 \mathrm{keV}$. Scanning electron microscope images were recorded with a Philips XL30 ESEM (Environmental Scanning Electron Microscope).

\section{Results and discussion}

\subsection{Powder characterization, TG-DTA, XRD and IR}

Heating of the (LaFe)-gel at $200{ }^{\circ} \mathrm{C}$ in air for $1 \mathrm{~h}$ resulted in a black-brown powder. Simultaneous TG/DTA investigations (heating rate $5 \mathrm{~K} / \mathrm{min}$ ) were carried out on this powder. As shown in Fig. 1a the sample shows a very slight weight loss of about $1.6 \%$ up to $190{ }^{\circ} \mathrm{C}$. At higher temperatures decomposition processes until $610^{\circ} \mathrm{C}$ lead to a total weight loss of approximately $31.0 \%$. During these decomposition processes we observed three strong exothermic DTA signals. The first exothermic process has an onset temperature of $230{ }^{\circ} \mathrm{C}$ and the last two signals occur between 310 and $470{ }^{\circ} \mathrm{C}$. These exothermic peaks suggest a selfcombustion-like process in which nitrate ions act as an oxidizing agent and starch as fuel. A last sharp weight loss occurs between 610 and $680{ }^{\circ} \mathrm{C}$ and is accompanied by a weak exothermic DTA signal with an onset temperature of $617^{\circ} \mathrm{C}$. IR spectroscopy of a sample heated up to $600{ }^{\circ} \mathrm{C}$ shows strong $\mathrm{CO}_{3}{ }^{2-}$ absorption bands, whereas XRD pattern shows only an X-ray amorphous product. From this finding the last weight loss can be assigned to the decomposition of carbonate compounds, probably lanthanum carbonate, formed during the combustion of the organic component. This weight loss is linked with the formation of the perovskite crystal lattice as revealed by XRD (see below). The total weight loss up to $900{ }^{\circ} \mathrm{C}$ is $35.3 \%$. XRD investigations of the final ochre coloured product indicated orthorhombic $\mathrm{LaFeO}_{3}[41]$.

TG/DTA measurements in argon atmosphere (Fig. 1b) show a very broad exothermic signal between 80 and $890{ }^{\circ} \mathrm{C}$. The multi-step decomposition process is finished only at $930{ }^{\circ} \mathrm{C}$ and lead to a total weight loss of $39.7 \%$. XRD measurements of the black-brown residue reveal a 
mixture of orthorhombic $\mathrm{LaFeO}_{3}$ (main phase), hexagonal $\mathrm{La}_{2} \mathrm{O}_{3}$ and small amounts of elemental iron [41]. This shows that oxygen is essential for the combustion-like decomposition process to yield phase pure $\mathrm{LaFeO}_{3}$.

Fig. 2 shows the phase evolution during the thermal decomposition of the orange ( $\mathrm{LaFe})$-gel heated in a muffle furnace in static air at various temperatures for $2 \mathrm{~h}$ (heating rate $5 \mathrm{~K} / \mathrm{min}$ ). The starting (LaFe)-gel (Fig. 2a) is X-ray amorphous. After calcination at $400{ }^{\circ} \mathrm{C}$ a brown $\mathrm{X}$ ray amorphous powder was obtained (Fig. 2b). A powder pattern after a heat treatment at 500 ${ }^{\circ} \mathrm{C}$ hints the presence of $\mathrm{La}_{2} \mathrm{O}_{3}$ [41] with low crystallinity, while no $\mathrm{LaFeO}_{3}$ was detected (Fig. 2c). At $550{ }^{\circ} \mathrm{C}$ besides reflections of $\mathrm{La}_{2} \mathrm{O}_{3}$ the evolution of $\mathrm{LaFeO}_{3}$ [41] can be observed (Fig. 2d) and a calcination temperature of $570{ }^{\circ} \mathrm{C}$ leads to an ochre fluffy phase-pure orthorhombic $\mathrm{LaFeO}_{3}$ powder (1a) (Fig. 2d). In contrast to the thermoanalytic results the formation of phase pure $\mathrm{LaFeO}_{3}$ is achieved even below $600{ }^{\circ} \mathrm{C}$, because of the long calcination time of $2 \mathrm{~h}$. With increasing calcination temperature all powders show only reflections according to orthorhombic $\mathrm{LaFeO}_{3}$ (Fig. 2f). The $\mathrm{LaFeO}_{3}$ powder 1a has a BET specific surface area of $25.7 \mathrm{~m}^{2} / \mathrm{g}$ corresponding to an equivalent particle size of $35 \mathrm{~nm}$, which can be considered the average size of the primary particles [42]. The volume-weighted average crystallite size (Scherrer equation) was calculated as $37 \mathrm{~nm}$ [37]. According to the Wilson-equation [39] the root-mean-square-strain was found to be 0.003 . TEM investigations (Fig. 3) of sample 1a show a highly agglomerated powder with porous features. The individual particles are mainly in the range of about 20 to $60 \mathrm{~nm}$. Sporadically, we find also particles up to about $100 \mathrm{~nm}$. The pores have diameters of about $15-50 \mathrm{~nm}$.

The XRD pattern of the nano-scaled $\mathrm{LaFeO}_{3}$ powder was refined on the basis of a primitive orthorhombic unit cell (space group: Pbnm) according to Marezio and Dernier [43]. We calculated the unit cell parameters as $\mathrm{a}=555.31 \mathrm{pm}, \mathrm{b}=556.29 \mathrm{pm}, \mathrm{c}=786.71 \mathrm{pm}, \mathrm{V}=$ $243.03 \cdot 10^{6} \mathrm{pm}^{3}$. These lattice constants correspond well to previously reported data for pure 
$\mathrm{LaFeO}_{3}[28,35,44]$. The lattice parameters do not significantly change with increasing calcination temperature.

Tab. 1 lists the BET specific surface areas, the equivalent particle sizes and the crystallite sizes of all synthesized $\mathrm{LaFeO}_{3}$ powders. As expected the specific surface area $\left(S_{B E T}\right)$ decrease with increasing calcination temperature. The logarithmic variation of $S_{B E T}$ versus the reciprocal absolute calcination temperature can be fitted by an Arrhenius equation [45] as shown in Fig. 4:

$S_{B E T}=A \cdot e^{\frac{-E_{A}}{R T}}$

where $A$ is a pre-exponential factor, $E_{A}$ is the activation energy for the reduction of the specific surface area, $T$ the absolute temperature and $R$ the universal gas constant. The Arrhenius plot given in Fig. 4 shows a positive slop because the specific surface area is reduced with increasing calcination temperature [45]. The activation energy was calculated as $E_{A}=28 \pm 2 \mathrm{~kJ} / \mathrm{mol}$. Andoulsi et al. [33] found a similar activation energy of $E_{A}=20 \mathrm{~kJ} / \mathrm{mol}$ during the calcination of nano- $\mathrm{LaFeO}_{3}$ prepared by a polymerizable complex method using ethylene glycol and citric acid. In contrast, the decomposition of a $\mathrm{La}\left[\mathrm{Fe}(\mathrm{CN})_{6}\right] \cdot 5 \mathrm{H}_{2} \mathrm{O}$ complex reveals an activation energy for the reduction of the specific surface area of 46 $\mathrm{kJ} / \mathrm{mol}[46]$.

FT-IR (ATR) spectra of the starting (LaFe)-gel and the corresponding calcination products after heating at $570{ }^{\circ} \mathrm{C}$ (powder 1a) and at $1000{ }^{\circ} \mathrm{C}$ (powder 1e) are shown in Fig. 5. The (LaFe)-gel (Fig. 5a) exhibits a broad band between about 3700 and $2600 \mathrm{~cm}^{-1}$ primarily caused by $\mathrm{O}-\mathrm{H}$ stretching vibrations from water molecules and $\mathrm{C}-\mathrm{H}$ stretching vibrations from the starch [47]. The $\mathrm{O}-\mathrm{H}$ bending mode results in an absorption band at $1633 \mathrm{~cm}^{-1}$ [48]. Additional bands at 1042 and $1328 \mathrm{~cm}^{-1}$ (shoulder at $1406 \mathrm{~cm}^{-1}$ ) are due to anti-symmetric and symmetric $\mathrm{N}-\mathrm{O}$ vibrations from the $\mathrm{NO}_{3}{ }^{-}$- ions [48]. The shoulder at $1406 \mathrm{~cm}^{-1}$ represents $\mathrm{O}-\mathrm{C}-\mathrm{H}, \mathrm{C}-\mathrm{C}-\mathrm{H}$, and $\mathrm{C}-\mathrm{O}-\mathrm{H}$ bending modes from the starch [47]. $\mathrm{C}-\mathrm{O}-\mathrm{H}$ groups cause 
$\mathrm{C}-\mathrm{O}$ stretching vibrations at $1152 \mathrm{~cm}^{-1}$, whereas $\mathrm{C}-\mathrm{O}$ stretching modes from $\mathrm{C}-\mathrm{O}-\mathrm{C}$ groups appear at 1079 and $1021 \mathrm{~cm}^{-1}$ [49].

Calcination at $570{ }^{\circ} \mathrm{C}$ (powder 1a, Fig. 5b) leads to a diminishing of most of the above described structures but also results in a sharp band at $541 \mathrm{~cm}^{-1}$, which can be assigned to a $\mathrm{Fe}-\mathrm{O}$ stretching vibration and further peaks at 397 and $316 \mathrm{~cm}^{-1}$ corresponding to $\mathrm{Fe}-\mathrm{O}-\mathrm{Fe}$ bending or deformation modes [50,51]. Weak adsorptions at about 1481 and $1392 \mathrm{~cm}^{-1}$ indicate unidentate adsorbed carbonate groups on the particle surface $[20,52,48]$, which disappear at higher calcination temperatures. Thermal treatment at $1000{ }^{\circ} \mathrm{C}$ (powder 1e) leads to a similar IR spectra, however the intensity of the carbonates bands are strongly reduced (Fig. 5c).

For comparison purposes we also investigated a coarse-grained $\mathrm{LaFeO}_{3}$ powder (2) obtained from a semi-conventional mixed-oxide process with calcination at $1200{ }^{\circ} \mathrm{C}$ for $8 \mathrm{~h}$. This reference sample has a specific surface area of $2.6 \mathrm{~m}^{2} / \mathrm{g}$ and thus an equivalent particle size of $348 \mathrm{~nm}$. The IR spectrum of powder 2 shows the typical Fe-O bands without any detectable carbonate bands (Fig. 5d).

\subsection{Sintering behaviour, microstructure and phase transition}

Fig. 6 shows non-isothermal dilatometric investigations up to $1500{ }^{\circ} \mathrm{C}$ in flowing air of compacts from the nano-powder 1a and the coarse-grained powder $\mathbf{2}$. Since the green compacts $1 \mathbf{a}\left(1.7 \mathrm{~g} / \mathrm{cm}^{3}\right)$ and $\mathbf{2}\left(4.0 \mathrm{~g} / \mathrm{cm}^{3}\right)$ strongly differ in their densities, the values of the relative shrinkage are not directly comparable. Therefore, from the relative shrinkages the evolution of the relative densities depending on temperature was calculated assuming an isotropic behaviour.

A slight shrinkage of compact $1 \mathrm{a}$ starts from about $750{ }^{\circ} \mathrm{C}$ and at $1130{ }^{\circ} \mathrm{C}$ the shrinkage increases considerably (Fig. 6). The shrinkage rate reaches a maximum value of $-1.19 \% / \mathrm{min}$ at $1335{ }^{\circ} \mathrm{C}$ as shown in the inset in Fig. 6 . Above $\approx 1450{ }^{\circ} \mathrm{C}$ we observe only a very slight 
length decrease. The calculated relative density reaches $91 \%$ at $1500{ }^{\circ} \mathrm{C}$. In contrast, the shrinkage of the coarse-grained compact 2 starts only at about $1100{ }^{\circ} \mathrm{C}$ and a significant increase in shrinkage can be observed above $1200{ }^{\circ} \mathrm{C}$. Two maxima of the shrinkage rate at $1355{ }^{\circ} \mathrm{C}$ and at $1406{ }^{\circ} \mathrm{C}$ with low rates of $-0.20 \% / \mathrm{min}$ and $-0.18 \% / \mathrm{min}$ were found. The densification leads to a relative density of only $74 \%$ up to $1500{ }^{\circ} \mathrm{C}$. The shrinkage rates of both compacts indicate sliding processes as the dominant mechanism, because diffusion processes alone would result in shrinkage rates of less than $0.1 \% / \mathrm{min}[53,54]$.

The final bulk densities of ceramic bodies of $\mathbf{1 a}$ and $\mathbf{2}$ after isothermal sintering at various temperatures with soaking times of 1 and 10 h, respectively, in static air are shown in Fig. 7 (heating-/cooling rate: $5 \mathrm{~K} / \mathrm{min}$ ). The absolute bulk densities of the sintered bodies were calculated from their weight and geometric dimensions. The relative bulk densities were calculated with respect to the crystallographic density of $6.64 \mathrm{~g} / \mathrm{cm}^{3}$ [55]. Coarse-grained powder compacts of $\mathbf{2}$ show an insufficient densification behaviour. Even after sintering at $1400{ }^{\circ} \mathrm{C}$ for $10 \mathrm{~h}$ we obtained ceramic bodies with a relative density of only $88 \%$ (Fig. 7). However, compacts from the nano-sized powder 1a show an improved densification. Sintering at $1300{ }^{\circ} \mathrm{C}(1 \mathrm{~h}$ dwelling time $)$ even leads to dense ceramic bodies with a relative bulk density of $90 \%$, which is raised to $95 \%$ at $1400-1450{ }^{\circ} \mathrm{C}(1 \mathrm{~h})$. The microstructures of these ceramic bodies are shown in Fig. 8. The SEM images reveal grain sizes between about 0.6-1.5 $\mu \mathrm{m}\left(1300{ }^{\circ} \mathrm{C}\right.$, Fig. 8a), $12-33 \mu \mathrm{m}\left(1350{ }^{\circ} \mathrm{C}\right), 15-36 \mu \mathrm{m}\left(1400{ }^{\circ} \mathrm{C}\right)$, and $30-85 \mu \mathrm{m}$ (1450 ${ }^{\circ} \mathrm{C}$, Fig. 8 b). By raising the sintering time to $10 \mathrm{~h}$ we obtained dense ceramics (rel. density $\geq 90 \%$ ) at a temperature of $1250{ }^{\circ} \mathrm{C}$ as shown in Fig. 7 . Up to $1350{ }^{\circ} \mathrm{C}$ the relative density increases to $97 \%$. After soaking time of $10 \mathrm{~h}$ the ceramics shows grains of about $0.8-3 \mu \mathrm{m}\left(1250{ }^{\circ} \mathrm{C}\right.$, Fig. $\left.8 \mathrm{c}\right), 2-7 \mu \mathrm{m}\left(1300{ }^{\circ} \mathrm{C}\right)$, and $16-70 \mu \mathrm{m}\left(1350{ }^{\circ} \mathrm{C}\right.$, Fig. $\left.8 \mathrm{~d}\right)$. The improved densification of powder $\mathbf{1 a}$ is a result of its nano-scaled morphology because of the large amount of amorphous or defect-rich grain boundaries, which promote sliding processes $[56,54]$. 
Fig. 9 shows DTA investigations of the orthorhombic $\leftrightarrows$ rhombohedral phase transition. The transition temperature was determined by the onset of the DTA signal during the heating phase [57]. The peak area of a DTA signal is proportional to the enthalpy change $\Delta H$ (Eq. 2) [58]:

$\Delta H=k \cdot \frac{A}{m}$

where $m$ is the sample mass, $A$ the peak area and $k$ is an instrument-specific proportionality factor. The DTA melting peak of high-purity gold with $\Delta H=12.36 \mathrm{~kJ} / \mathrm{mol}\left(1064{ }^{\circ} \mathrm{C}\right)$ [59] was used to determine the proportionality factor $(k)$ assuming $k$ does not significantly change in the studied temperature interval of the phase transition of $\mathrm{LaFeO}_{3}$.

In the literature phase transition temperatures between $980{ }^{\circ} \mathrm{C}$ and $1005{ }^{\circ} \mathrm{C}$ have been reported [17,60,61]. DTA measurements on $\mathrm{LaFeO}_{3}$ powders 1c, 1d and 1e (see also Tab. 1) reveal orthorhombic $\leftrightarrows$ rhombohedral phase transition temperatures of 992,993 and $998{ }^{\circ} \mathrm{C}$ (Fig. 9a-c). The corresponding enthalpy changes were calculated as 55, 70 and $200 \mathrm{~J} / \mathrm{mol}$, respectively. Investigations on powders $\mathbf{1 a}$ and $\mathbf{1 b}$ show very weak DTA signals, which could not be exactingly analyzed. Fig. 9d represents the DTA curve of a $\mathrm{LaFeO}_{3}$ bulk ceramic body of $1 \mathrm{a}$ sintered at $1300{ }^{\circ} \mathrm{C}$ for $1 \mathrm{~h}$. The onset temperature and enthalpy change of the orthorhombic $\leftrightarrows$ rhombohedral phase transition are $980{ }^{\circ} \mathrm{C}$ and $\Delta H=410 \mathrm{~J} / \mathrm{mol}$, respectively. The coarse-grained powder 2 exhibits a similar transition temperature of $989^{\circ} \mathrm{C}$ (Fig. 9e). The corresponding enthalpy change of $420 \mathrm{~J} / \mathrm{mol}$ is not significant different from the bulk ceramic. The similar transition temperatures and enthalpy changes between powder 2 (particle-size: $348 \mathrm{~nm}$ ) and the ceramic body prepared from the nano-powder 1a (grain-size: 0.6-1.5 $\mu \mathrm{m}$ ) are due the coarse-grained character of both samples. The DTA investigations during the phase transition show that a reduction of the particle size leads to a reduction of the enthalpy change, which has also been observed in other systems $[62,63,64]$. The reduction of the enthalpy changes with decreasing particle sizes is primarily a surface effect, because of the 
increasing surface/volume ratio in small particles as pointed out by various experimental and theoretical studies $[65,66,67,68,69,70]$.

Slightly higher transition temperatures of fine-grained $\mathrm{LaFeO}_{3}$ powders compared to bulk ceramics are also described by Fossdal et al. [61]. The magnetic phase transition (not shown) was observed by a broad DTA signal between about $460-480{ }^{\circ} \mathrm{C}$ in all samples.

The orthorhombic $\leftrightarrows$ rhombohedral phase transition was also observed by dilatometric measurements on $\mathrm{LaFeO}_{3}$ ceramic bodies (sintered at 1300 and $1400{ }^{\circ} \mathrm{C}$ ) as it gives rise to a sudden length change of the curve indicating a first-order character of the phase transition (inset in Fig. 9). The transition temperature was determined to $1004{ }^{\circ} \mathrm{C}$ at the point of inflection of the measured curve.

The average linear thermal expansion coefficient $\left(\alpha_{d i l}\right)$ of bulk ceramics was determined by dilatometric measurements using equation 3 [71,72]:

$\alpha_{d i l}=\frac{\Delta L}{L_{0} \Delta T}$

( $L_{0}$ - lengths of the ceramic body at RT, $\Delta L$ - length change in the temperature range $\Delta T$ ). Between 220 and $450{ }^{\circ} \mathrm{C}$ an average linear thermal expansion coefficient of $11.8 \cdot 10^{-6} \mathrm{~K}^{-1}$ was found, which corresponds well with literature data [61].

\section{Conclusion}

Nano-sized $\mathrm{LaFeO}_{3}$ powders were synthesized by a soft-chemistry method using starch as a complexing agent and gellant. Calcination of the resulting (LaFe)-gel at $570{ }^{\circ} \mathrm{C}$ for $2 \mathrm{~h}$ leads to a very fluffy phase-pure $\mathrm{LaFeO}_{3}$ powder (1a) with a specific surface area of $25.7 \mathrm{~m}^{2} / \mathrm{g}$ and a crystallite size of about $37 \mathrm{~nm}$. TEM images shows a porous powder with particles mainly in the range of $20-60 \mathrm{~nm}$. This nano-sized $\mathrm{LaFeO}_{3}$ powder shows an improved sintering behaviour compared to a sample prepared by semi-conventional solid-state reaction. Dilatometric measurements of compacts from the nano-powder 1a reveal that the beginning 
of the shrinkage is downshifted by more than $300{ }^{\circ} \mathrm{C}$ compared with the coarse-grained powder 2. Dense ceramic bodies (relative density $\geq 90 \%$ ) from powder 1a can be obtained after isothermal sintering at $1250{ }^{\circ} \mathrm{C}$ for $10 \mathrm{~h}$. The orthorhombic $\leftrightarrows$ rhombohedral phase transition of $\mathrm{LaFeO}_{3}$ ceramics (grain-sizes: $>1 \mu \mathrm{m}$ ) was found to be $980{ }^{\circ} \mathrm{C}$ and is connected with an enthalpy change of $\Delta H=410 \mathrm{~J} / \mathrm{mol}$. The average linear thermal expansion coefficient between 220 and $450{ }^{\circ} \mathrm{C}$ was calculated to be $11.8 \cdot 10^{-6} \mathrm{~K}^{-1}$. The nano- and fine-grained $\mathrm{LaFeO}_{3}$ powders (crystallite sizes: 37-166 nm) show both slightly higher transition temperatures $\left(992-998^{\circ} \mathrm{C}\right.$ ) and a decrease of $\Delta H$ with decreasing particle-/crystallite size.

Due to its large specific surface area, powder 1a is a promising candidate for application as catalyst.

\section{Acknowledgements}

The authors thank Dr. Th. Müller for TG/DTA measurements. We are also grateful to Prof. Dr. D. Hesse (Max Planck Institute of Microstructure Physics, Halle/Saale) for the TEM images. Financial support by the German Science Foundation within the Collaborative Research Centre (SFB 762) "Functionality of Oxide Interfaces" is gratefully acknowledged. 
Table 1

Variation of $\mathrm{S}_{\mathrm{BET}}$ and particle-/crystallite size with calcination conditions

\begin{tabular}{lllll}
\hline Powder & $\begin{array}{l}\text { Calcination } \\
\text { condition }\end{array}$ & $\begin{array}{l}\mathrm{S}_{\mathrm{BET}} \\
\left(\mathrm{m}^{2} / \mathrm{g}\right)\end{array}$ & $\begin{array}{l}\mathrm{d}_{\mathrm{BET}} \\
(\mathrm{nm})\end{array}$ & $\begin{array}{l}\mathrm{d}_{\text {cryst }} \\
(\mathrm{nm})^{2)}\end{array}$ \\
\hline $\mathbf{1 a}$ & $570^{\circ} \mathrm{C} / 2 \mathrm{~h}$ & 25.7 & 35 & 37 \\
$\mathbf{1 b}$ & $700{ }^{\circ} \mathrm{C} / 2 \mathrm{~h}$ & 17.1 & 53 & 54 \\
$\mathbf{1 c}$ & $800{ }^{\circ} \mathrm{C} / 2 \mathrm{~h}$ & 12.0 & 75 & 80 \\
$\mathbf{1 d}$ & $900^{\circ} \mathrm{C} / 2 \mathrm{~h}$ & 9.1 & 99 & 106 \\
$\mathbf{1 e}$ & $1000^{\circ} \mathrm{C} / 2 \mathrm{~h}$ & 6.5 & 139 & 166 \\
$\mathbf{2}$ & $1200^{\circ} \mathrm{C} / 8 \mathrm{~h}$ & 2.6 & 348 & - \\
\hline
\end{tabular}

1) calculated from the specific surface area

2) volume-weighted average crystallite size (Scherrer equation) 

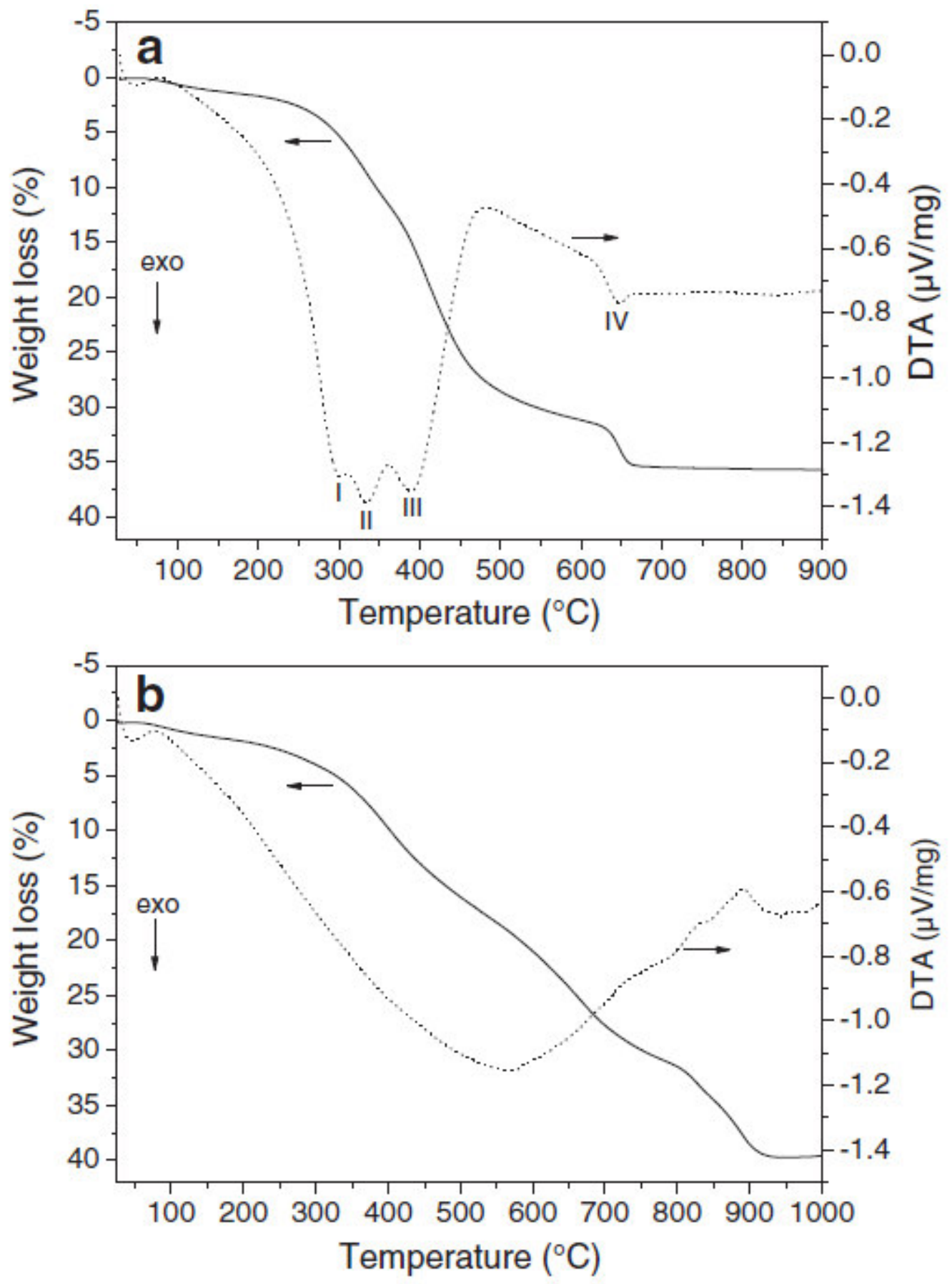

Fig. 1. Simultaneous TG/DTA investigations of a preheated (LaFe)-gel in flowing air (a) and argon atmosphere (b) with heating rates of $5 \mathrm{~K} / \mathrm{min}$. In (a) the exothermic processes have maximum peak temperatures of $302{ }^{\circ} \mathrm{C}$ (I), $334{ }^{\circ} \mathrm{C}$ (II), $388{ }^{\circ} \mathrm{C}$ (III), and $649{ }^{\circ} \mathrm{C}$ (IV), respectively. 


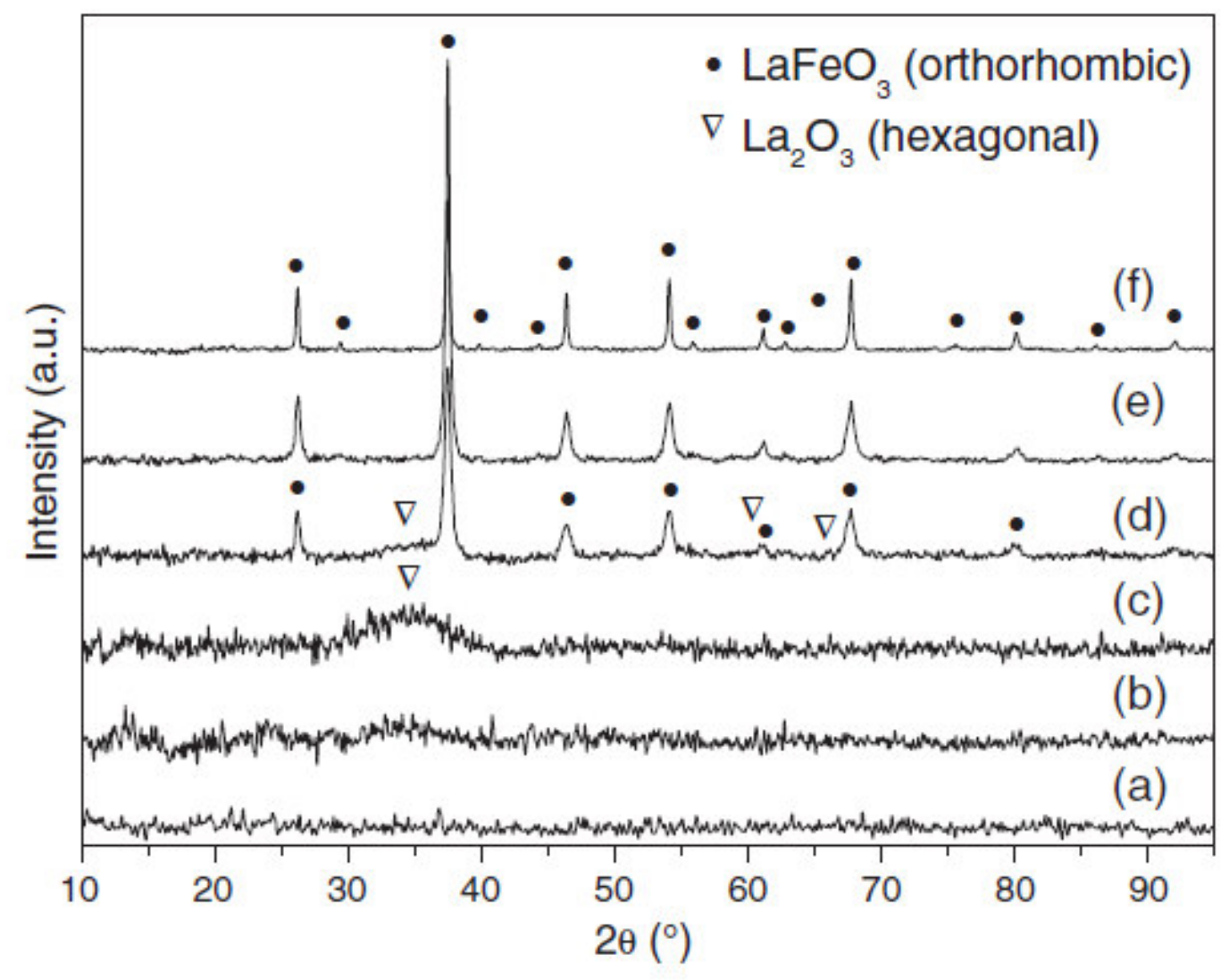

Fig. 2. Room temperature XRD patterns of the (LaFe)-gel (a) and calcination products (b-f) at various temperatures (soaking time $2 \mathrm{~h}$, rate $5 \mathrm{~K} / \mathrm{min}$ ): (b) $400{ }^{\circ} \mathrm{C}$, (c) $500{ }^{\circ} \mathrm{C}$, (d) $550{ }^{\circ} \mathrm{C}$, (e) $570{ }^{\circ} \mathrm{C}$ (powder 1a), and (f) $1000{ }^{\circ} \mathrm{C}$ (powder 1e).
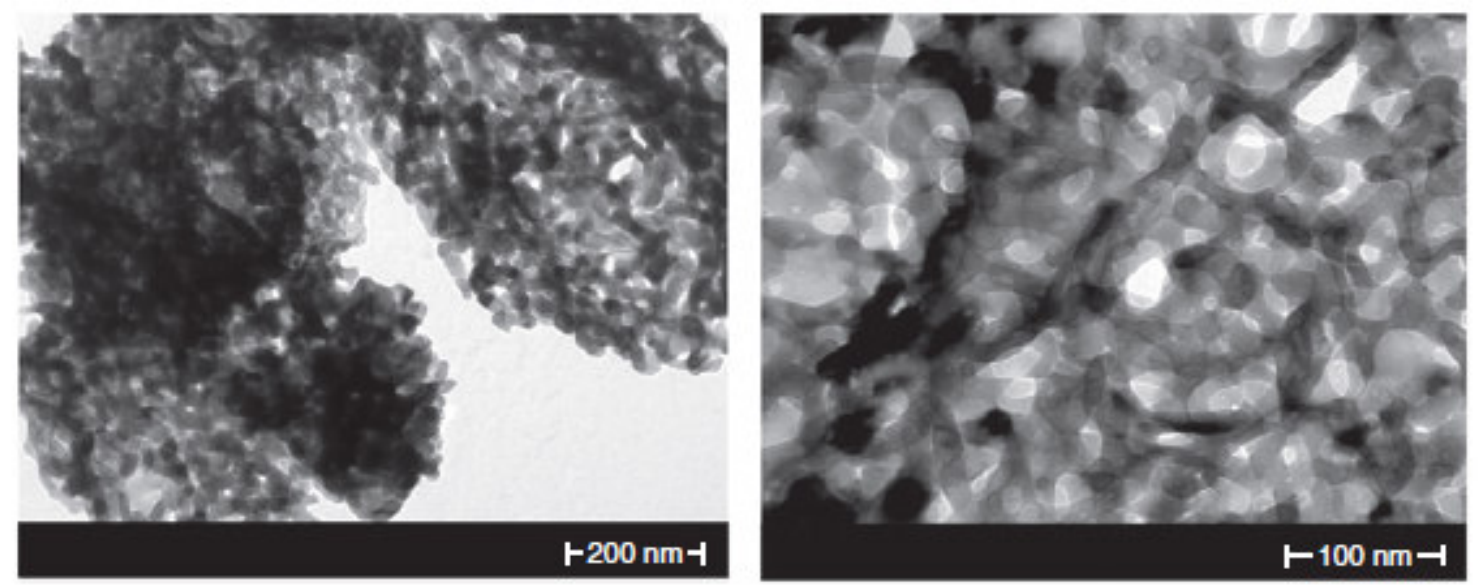

Fig. 3. TEM images of powder 1a. 


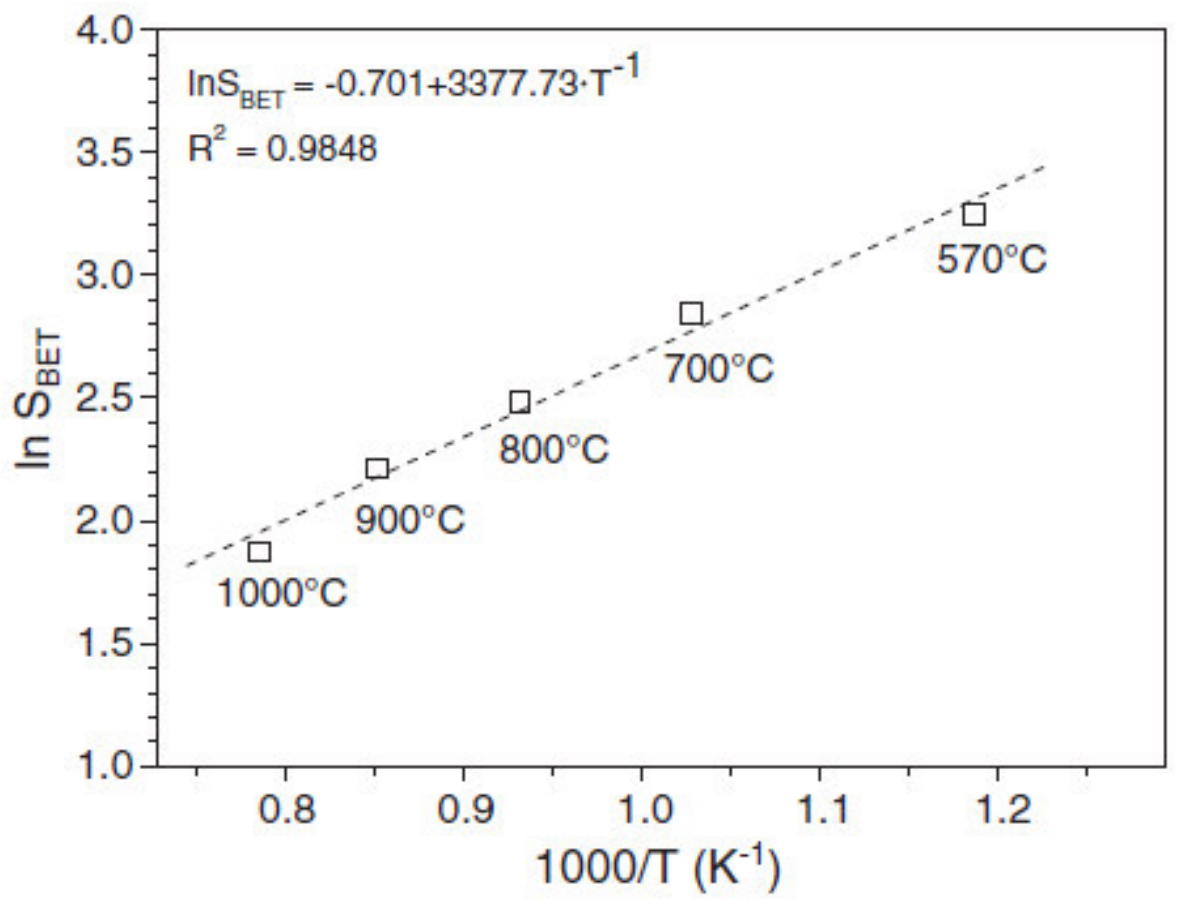

Fig. 4. Arrhenius plot of the specific surface area versus reciprocal calcination temperature of powders 1a-1e.

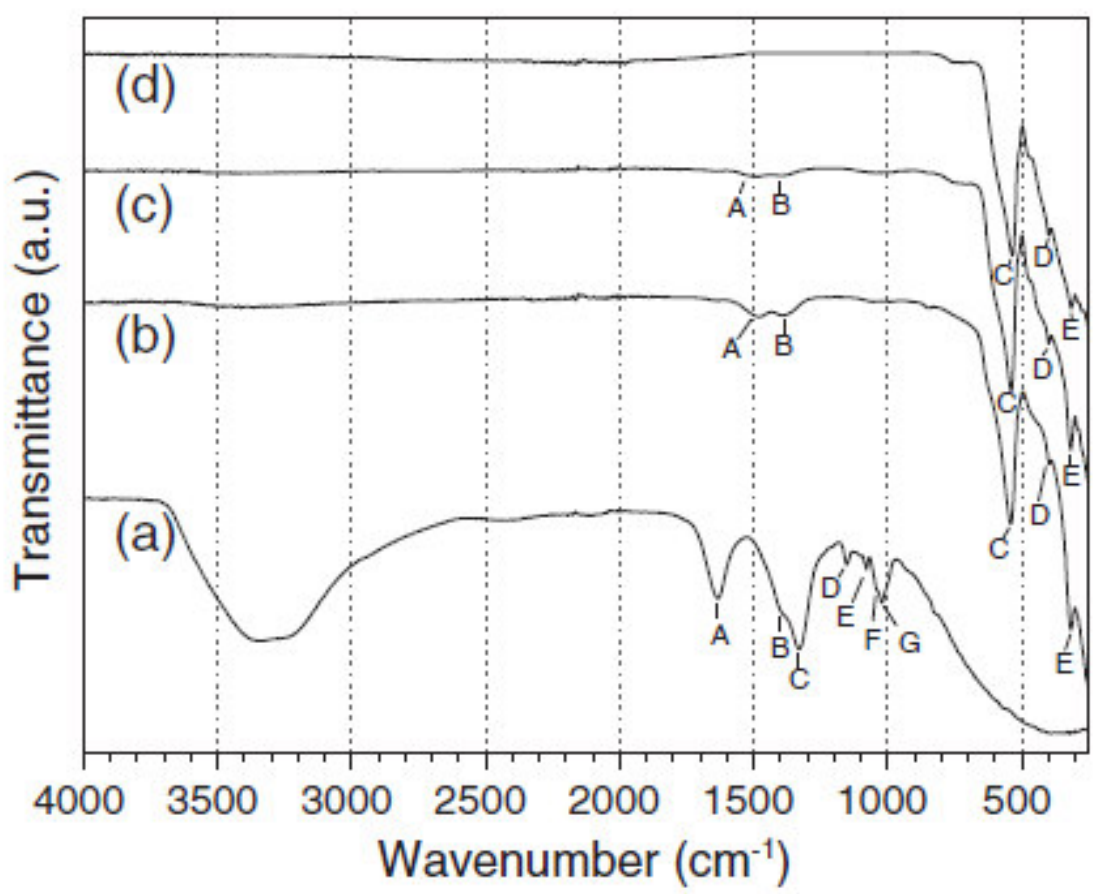

Fig. 5. FT-IR spectra (ATR technique) of (a) (LaFe)-gel, (b) powder 1a, (c) powder 1e, and (d) powder 2. Band positions ( $\mathrm{cm}^{-1}$ ), graph (a): 1633 (A), 1406 (B), 1328 (C), 1152 (D), 1079 (E), 1042 (F), and 1021 (G); graph (b): 1481 (A), 1392 (B), 541 (C), 397 (D), and 316 (E); graph (c): 1486 (A), 1392 (B), 539 (C), 398 (D), and 316 (E); graph (d): 534 (C), 399 (D), and 315 (E). 


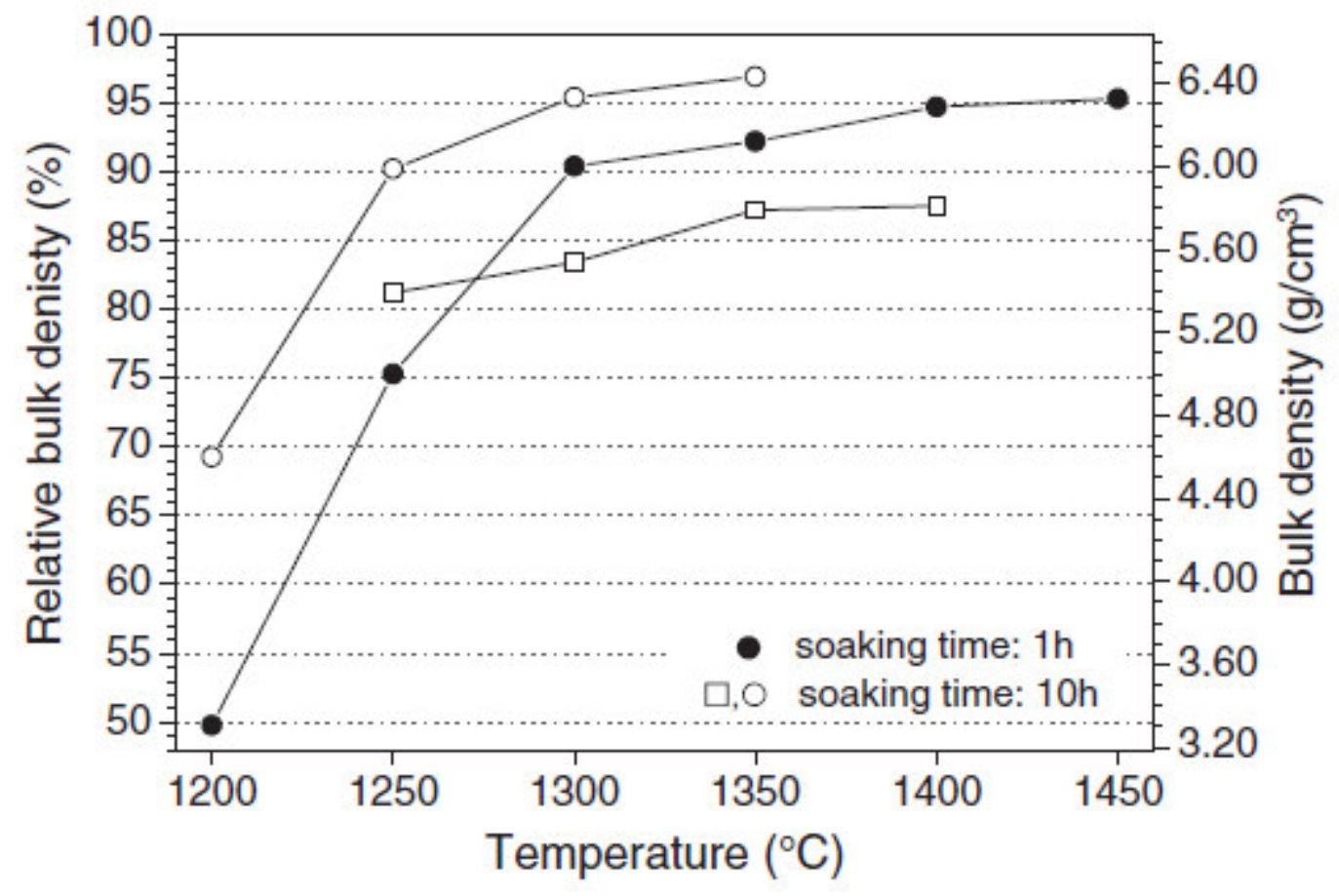

Fig. 7. Final bulk densities versus sintering temperature of ceramic bodies of $1 \mathrm{a}(\mathrm{O}, \mathbf{\bullet})$ and 2 ( $\square$ ) after soaking times of $1 \mathrm{~h}$ and $10 \mathrm{~h}$ (heating-/cooling rate: $5 \mathrm{~K} / \mathrm{min}$ ). 


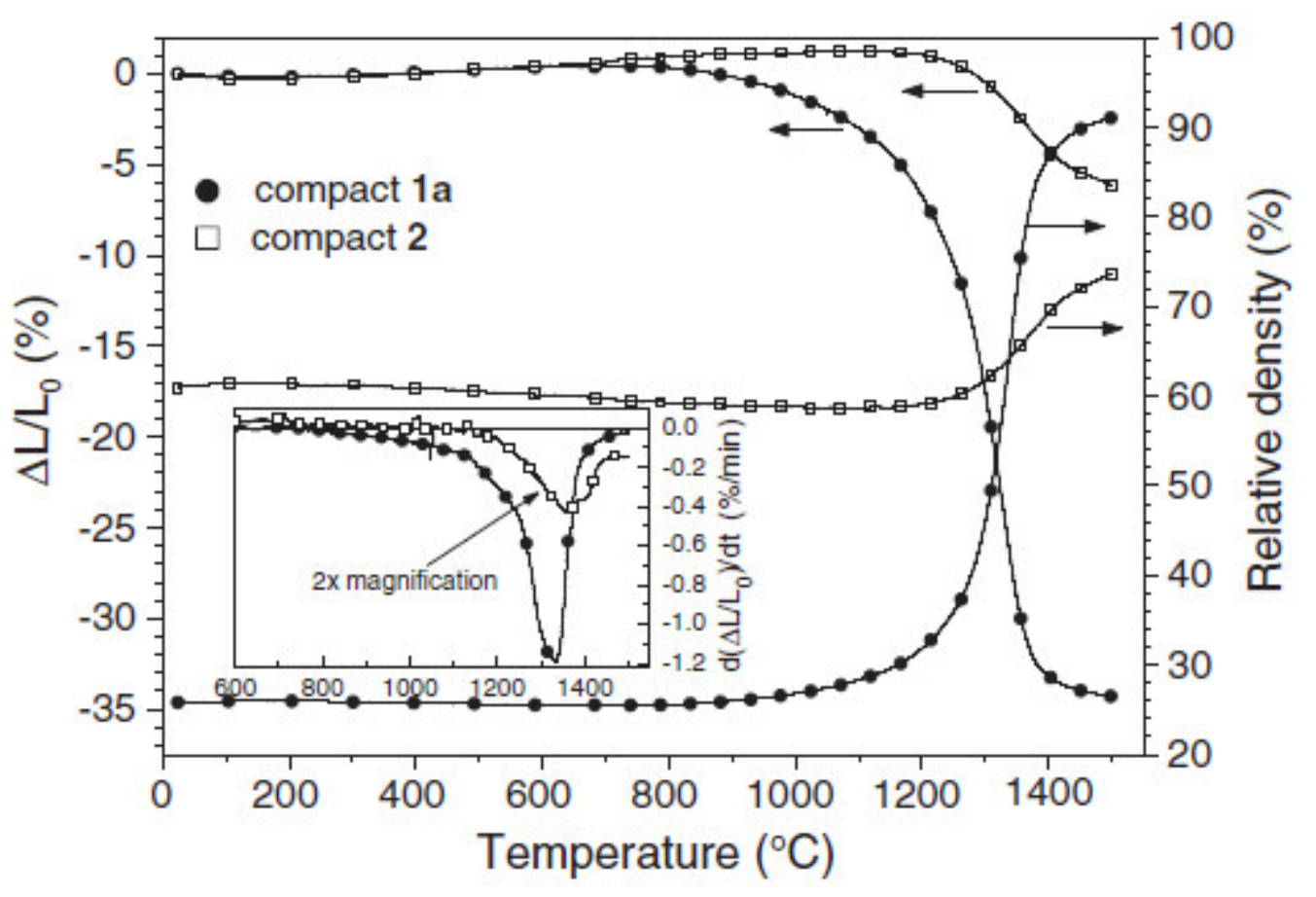

Fig. 6. Non-isothermal dilatometric measurements of green bodies of 1a and $\mathbf{2}$ in flowing air (heating rate $5 \mathrm{~K} / \mathrm{min}$ ). Relative densities (in relation to $6.64 \mathrm{~g} / \mathrm{cm}^{3}$ ) were calculated assuming an isotropic shrinkage behaviour. The inset shows the relative shrinkage rates $\left(\mathrm{d}\left(\Delta L / L_{0}\right) / \mathrm{dt}\right.$ ). The green densities were $1.7 \mathrm{~g} / \mathrm{cm}^{3}(1 \mathrm{a})$ and $4.0 \mathrm{~g} / \mathrm{cm}^{3}(2)$, respectively. Every 150 th data point is marked by a symbol.
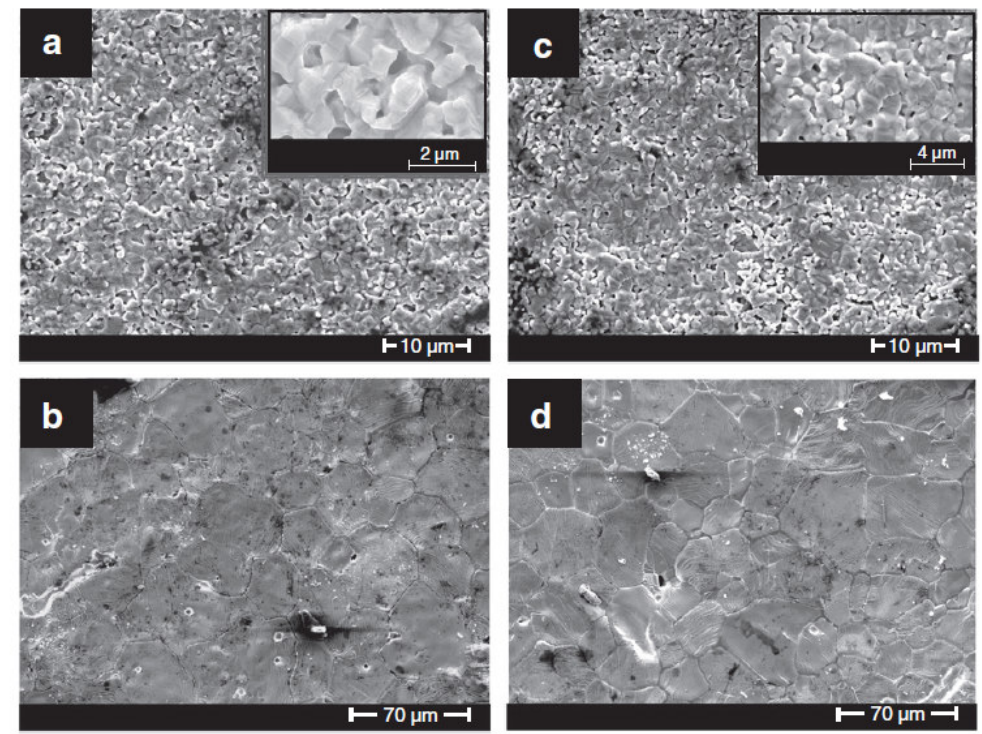

Fig. 8. SEM surface images of ceramic bodies of $1 \mathrm{a}$ after various isothermal sintering conditions (heating rate $5 \mathrm{~K} / \mathrm{min}$ ): a) $1300{ }^{\circ} \mathrm{C}, 1 \mathrm{~h}$; b) $1450{ }^{\circ} \mathrm{C}$, $1 \mathrm{~h}$; c) $1250{ }^{\circ} \mathrm{C}, 10 \mathrm{~h}$; and d) $1350{ }^{\circ} \mathrm{C}, 10 \mathrm{~h}$. 


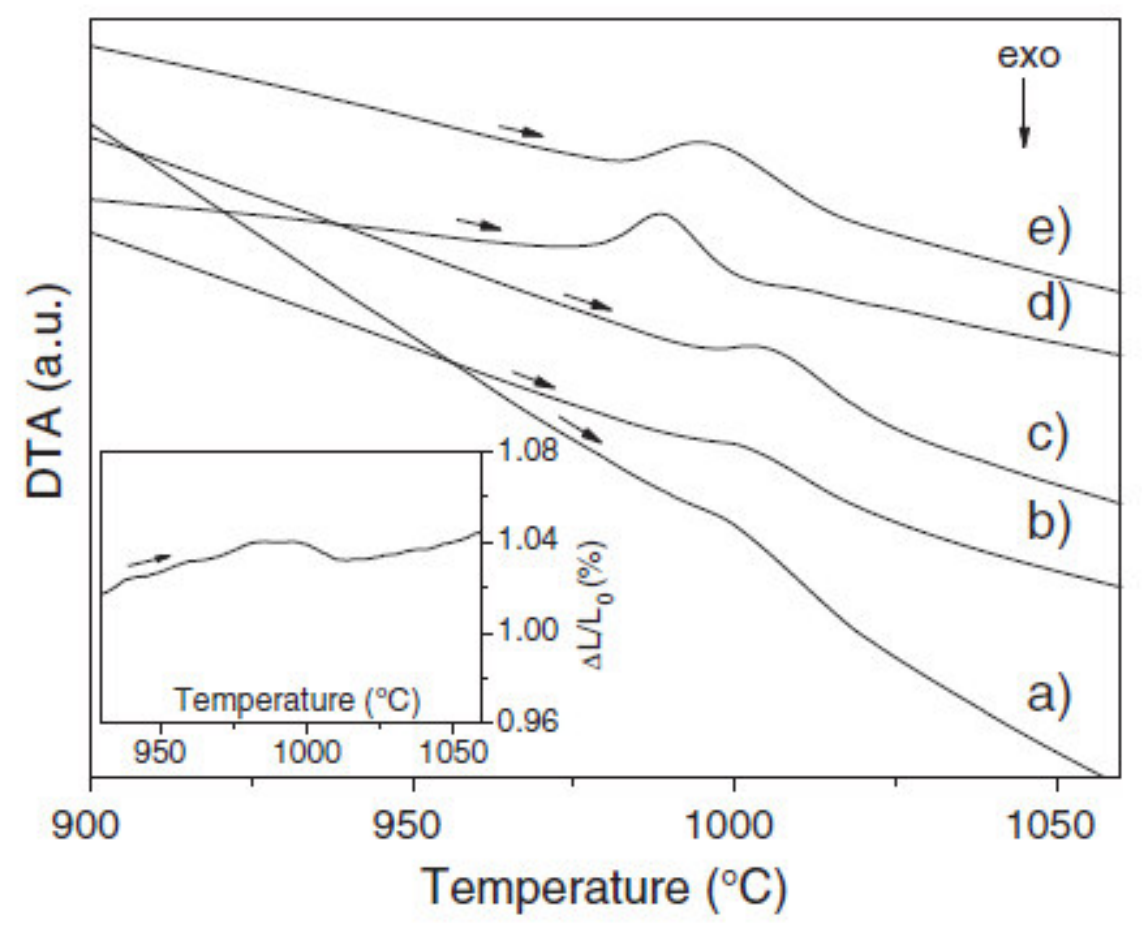

Fig. 9. DTA signals in flowing air during the orthorhombic $\leftrightarrows$ rhombohedral phase transition of various $\mathrm{LaFeO}_{3}$ samples (rate $20 \mathrm{~K} / \mathrm{min}$ ). (a) powder 1c, (b) powder 1d, (c) powder $1 \mathrm{e},(\mathrm{d})$ ceramic body of $1 \mathrm{a}$ sintered at $1300{ }^{\circ} \mathrm{C}(1 \mathrm{~h})$, and (e) mixed-oxide powder 2 . The inset shows the dilatometric measurement of the expansion of the $\mathrm{LaFeO}_{3}$ ceramics $\left(1300{ }^{\circ} \mathrm{C}, 1 \mathrm{~h}\right.$ ) during the phase transition (rate $10 \mathrm{~K} / \mathrm{min}$, flowing air).

\section{References}

[1] J. Deng, H. Dai, H. Jiang, L. Zhang, G. Wang, H. He, C.T. Au, Environ. Sci. Technol. 44 (2010) 2618-2623.

[2] Y.-G. Cho, K.-H. Choi, Y.-R. Kim, J.-S. Jung, S.-H. Lee, Bull. Korean Chem. Soc. 30 (2009) 1368-1372.

[3] A.E. Giannakas, A.K. Ladavos, P.J. Pomonis, Appl. Catal. B Environm. 49 (2004) $147-158$. 
[4] A.A. Barresi, D. Mazza, S. Ronchetti, R. Spinicci, M.Vallino, Stud. Surf. Sci. Catal. $130(2000)$ 1223-1228.

[5] F. Magalhães, F.C.C. Moura, J.D. Ardisson, R.M. Lago, Mater. Res. 11 (2008) 307312.

[6] J. Faye, E. Guelou, J. Barrault, J.M. Tatibouet, S. Valange, Top. Catal. 52 (2009) $1211-1219$

[7] K.M. Parida, K.H. Reddy, S. Martha, D.P. Das, N. Biswal, Int. J. Hydrogen. Energ. 35 (2010) 12161-12168.

[8] P. Tang, M. Fu, H. Chen, F. Cao, Mater. Sci. Forum 694 (2011) 150-154.

[9] P. Song, H. Quin, L. Zhang, K. An, Z. Lin, J. Hu, M. Jiang, Sens. Actuators B104 (2005) 312-316.

[10] E.N. Armstrong, T. Striker, V. Ramaswamy, J.A. Ruud, E.D. Wachsman, Sens. Actuators B158 (2011) 159-170.

[11] P. Song, Q. Wang, Z. Zhang, Z. Yang, Sens. Actuators B147 (2010) 248-254.

[12] K. Huang, H.Y. Lee, J.B. Goodenough, J. Electrochem.Soc. 145 (1998) 3220-3227.

[13] T.H. Shin, S. Ida, T. Ishihara, J. Am. Chem. Soc. 133 (2011) 19399-19407.

[14] M.-H. Hung, M.V.M. Rao, D.-S. Tsai, Mater. Chem. Phys. 101 (2007) 297-302.

[15] F. Bidrawn, S. Lee, J.M. Vohs, R.J. Gorte, J. Electrochem. Soc. 155 (2008) B660B665.

[16] J.W. Seo, E.E. Fullerton, F. Nolting, A. Scholl, J. Fompeyrine, J.-P. Locquet, J. Phys. Condens. Matter 20 (2008) 264014.

[17] S. Geller, P.M. Raccah, Phys. Rev. B2 (1970) 1167-1172.

[18] R. Köferstein, L. Jäger, M. Zenkner, S.G. Ebbinghaus, J. Eur. Ceram. Soc. 29 (2009) $2317-2324$. 
[19] A.V. Orlov, O.A. Shlyakhtin, A.L. Vinokurov, A.V. Knotko, Y.D. Tretyakov, Inorg. Mater. 41 (2005) 1194-1200.

[20] E. Traversa, P. Nunziante, M. Sakamoto, Y. Sadaoka, M.C. Carotta, G. Martinelli, J. Mater. Res. 13 (1998) 1335-1344.

[21] G. Shabbir, A.H. Qureshi, K. Saeed, Mater. Lett. 60 (2006) 3706-3709.

[22] H. Xu, X. Hu, L. Zhang, Cryst. Growth Des. 8 (2008) 2061-2065.

[23] X. Li, H. Zhang, M. Zhao, S. Li, B. Xu, J. Mater. Chem. 2 (1992) 253-254.

[24] S. Li, L. Jing, W. Fu, L. Yang, B. Xin, H. Fu, Mater. Res. Bull. 42 (2007) 203-212.

[25] M.B. Bellakki, B.J. Kelly, V. Manivannan, J. Alloys Compd. 489 (2010) 64-71.

[26] F.-T Li, Y. Liu, R.-H. Liu, Z.-M. Sun, D.-S. Zhao, C.-G. Kou, Mater. Lett. 64 (2010) $223-225$.

[27] A.E. Giannakas, A.K. Ladavos, P.J. Pomonis, Appl. Catal. B-Environ. 49 (2004) 147158.

[28] J. Prado-Gonjal, A.M. Arevalo-Lopez, E. Mora, Mater. Res. Bull. 46 (2011) 222-230.

[29] T. Liu, Y. Xu, Mater. Chem. Phys. 129 (2011) 1047-1050.

[30] F.-T Li, Y. Liu, Z.-M. Sun, R.-H. Liu, C.-G Kou, Y. Zhao, D.-S Zhao, Mater. Lett. 65 (2011) 406-408.

[31] M.B. Bellakki, V. Manivannan, J. Das, Mater. Res. Bull. 44 (2009) 1522-1527.

[32] H. Shen, G. Cheng, A. Wu, J. Xu, J. Zhao, Phys. Status Solidi A206 (2009) $1420-1424$.

[33] R. Andoulsi, K. Horchani-Naifer, M. Férid, Ceramica 58 (2012) 126-130.

[34] Y. Wang, J. Zhu, L. Zhang, X. Yang, L. Lu, X. Wang, Mater. Lett. 60 (2006) $1767-1770$.

[35] J. Wang, Q. Liu, D. Xue, F. Li, J. Mater. Sci. Lett. 21 (2002) 1059-1062.

[36] W. Kraus, G. Nolze, Powder Diffr. 13 (1998) 256-259. 
[37] Th.H. De Keilser, E.J. Mittermeijer, H.C.E Rozendaal, J. Appl. Cryst. 16 (1983) $309-316$.

[38] Program WinXPOW v1.06, Stoe \& Cie GmbH, Darmstadt (1999).

[39] A.R. Stokes, A.J.C. Wilson, Proc. Phys. Soc. 56 (1944) 174-181.

[40] V.D. Allred, S.R. Buxton, J.P. McBride, J. Phys. Chem. 61 (1957) 117-120.

[41] PDF 2 (International Centre for Diffraction Data, Pennsylvania) 2001, $\mathrm{LaFeO}_{3}$ [742203], $\mathrm{La}_{2} \mathrm{O}_{3}$ [73-2141], $\mathrm{Fe}$ [85-1410].

[42] M.T. Buscaglia, M. Bassoli, V. Buscaglia, R. Alessio, J. Am. Ceram. Soc. 88 (2005) 2374-2379.

[43] M. Marezio and P.D. Dernier, Mater. Res Bull. 6 (1971) 23-30.

[44] M. Kumar, S. Srikanth, B. Ravikumar, T.C. Alex, S.K. Das, Mater. Chem. Phys. 113 (2009) 803-815.

[45] G.E. Shter, A.R. Schwartzman, G.S. Grader, Appl. Supercond. 3 (1995) 543-550.

[46] S. Nakayama, J. Mater. Sci. 36 (2001) 5643-5648.

[47] P.R. Changa, P. Zheng, B. Liu, D.P. Anderson, J. Yu, X. Ma, J. Hazard. Mater. 186 (2011) 2144-2150.

[48] K. Nakamoto, Infrared and Raman Spectra of Inorganic and Coordination Compounds. John Wiley \& Sons, USA, 1986.

[49] J.M. Fang, P.A. Fowler, J. Tomkinson, C.A.S. Hill, Carbohydr. Polym. 47 (2002) $245-252$.

[50] G.V. Subba Rao, C.N.R. Rao, J.R. Ferraro, Appl. Spectrosc. 24 (1970) 436-445.

[51] M.A. Ahmed, R. Seoudi, S.I. El-dek, J. Mol. Struct. 754 (2005) 41-44.

[52] H.-M. Zhang, Y. Teraoka, N. Yamazoe, Chem. Lett. (1987) 665-668.

[53] R. Köferstein, L. Jäger, M. Zenkner, S.G. Ebbinghaus, J. Eur. Ceram. Soc. 29 (2009) $2317-2324$ 
[54] W. Schatt, Sintervorgänge. VDI-Verlag, Düsseldorf, 1992, pp. 78-100.

[55] L. Prado-Gonjal, A.M. Arevalo-Lopez, E. Moran, Mater. Res. Bull. 46 (2011) $222-230$.

[56] W. Schatt, Z. Metallkde. 80 (1989) 809-816.

[57] H. K. Cammenga and M. Epple, Angew. Chem. 107 (1995) 1284-1301.

[58] M.E. Brown, Introduction to Thermal Analysis. Chapman and Hall, New York, 1988.

[59] J.E. Callanan, J. Thermal. Anal. 45 (1995) 359-368.

[60] T. Ohzeki, T. Hashimoto, K. Shozugawa, M. Matsuo, Solid State Ionics 181 (2010) $1771-1782$.

[61] A. Fossdal, M. Menon, I. Wærnhus, K. Wiik, M.-A. Einarsrud, T. Grande, J. Am. Ceram. Soc., 87 (2004) 1952-1958.

[62] R. Köferstein, L. Jäger, M. Zenkner, S.G. Ebbinghaus, Mater. Chem. Phys. 119 (2010) 118-122.

[63] W.L. Zhong, B. Jiang, P. L. Zhang, J.M. Ma, H.M. Cheng, Z.H. Yang, L.X. Li, J. Phys.: Condens. Matter. 5 (1993) 2619-2624.

[64] X. M. Chen, G.T. Fei, K. Zheng, J. Phys.: Condens. Matter 21 (2009) 245403.

[65] J. Sun, S.L. Simon, Thermochim. Acta 463 (2007) 32-40.

[66] L.H. Liang, M. Zhao, Q. Jiang, J. Mater. Sci. Lett. 21 (2002) 1843-1845.

[67] M. Zhang, M.Yu. Efremov, F. Schiettekatte, E.A. Olson, A.T. Kwan, S.L. Lai, T. Wisleder, J.E. Greene, L.H. Allen, Phys. Rev. B62 (2000) 10548-10557.

[68] R. Lipowsky, Ferroelectrics 73 (1987) 69-81.

[69] L. H. Liang, G.W. Yang, B. Li, J. Phys. Chem. B109 ( 2005) 16081-16083.

[70] M. Kuwabara, H. Matsuda, N. Kurata, E. Matsuyama, J. Am. Ceram. Soc. 80 (1997) $2590-2596$.

[71] J.D James, J.A Spittle, S.G.R Brown, R.W Evans, Meas. Sci. Technol. 12 (2001) R1R15. 
[72] W.F. Hemminger and H.K. Cammenga, Methoden der Thermischen Analyse. Springer-Verlag, Berlin-Heidelberg, 1989. 